\title{
A inclusão das pessoas com deficiências (PDC) - um diálogo inexistente com a teoria
}

\section{organizacional}

\author{
The inclusion of people with disabilities (PDC) - a nonexistent dialogue with organizational theory \\ La inclusión de personas con discapacidades (PDC): un diálogo inexistente con la teoría \\ organizacional
}

Recebido: 22/08/2021 | Revisado: 28/08/2021 | Aceito: 30/08/2021 | Publicado: 02/09/2021

\author{
Vaner José do Prado \\ ORCID: https://orcid.org/0000-0002-8752-6077 \\ Universidade Salvador, Brasil \\ E-mail: vaner.prado@unifacs.br \\ Luciana Rodrigues dos Santos \\ ORCID: https://orcid.org/0000-0001-7986-7579 \\ Universidade Salvador, Brasil \\ E-mail: luciana_rs22@hotmail.com
}

\begin{abstract}
Resumo
Avanços nas legislações das sociedades contemporâneas têm possibilitado novos olhares para as minorias. O Estado brasileiro contemplou grupos sociais vitimados por alguma forma de alijamento de participação, a exemplo, dos sistemas de cotas, mecanismo utilizado para promover a inclusão da pessoa com deficiência (PDC). Assim, é válido lembrar que as pessoas com deficiências sempre estiveram à margem do processo de inclusão e cidadania, sendo tolhida até mesmo de seu direito à vida. A questão problema busca uma compreensão da existência ou não de um tecido conceitual (para além do campo legal), que possa integrar a inclusão das pessoas com deficiência (PCD's), com as bases da teoria organizacional, com o mundo do trabalho (comportamento e dinâmica das empresas) e com a responsabilidade social das empresas, para efetivar o acolhimento das PCD's e compreender suas contribuições com as atividades empresariais? O objetivo é analisar a existência desse tecido conceitual integrado, capaz de propiciar um melhor entendimento dos construtos e aspectos legais que definem pessoas com deficiência e sua inclusão, no campo da teoria organizacional e da responsabilidade social, visando esclarecer melhor os pressupostos integrativos para a inclusão das pessoas com deficiência no mundo do trabalho (campo da dinâmica empresarial). A pesquisa possui natureza descritiva/exploratória. Seus principais resultados estão sintetizados nos aspectos de uma inclusão da PCD ainda restrita ao campo legal, com uma exclusão total do tema pela teoria organizacional e por inclusão no campo empresarial ainda sendo legitimada por um conceito de responsabilidade social, que cambaleante, oscila entre responsabilidade real e modismo.
\end{abstract}

Palavras-chave: Pessoa com deficiência; Teoria organizacional; Responsabilidade social; Inclusão.

\begin{abstract}
Advances in the legislation of contemporary societies have enabled new perspectives on minorities. The Brazilian State contemplated social groups victimized by some form of excluding participation, such as quota systems, a mechanism used to promote the inclusion of people with disabilities (PDC). Thus, it is worth remembering that people with disabilities have always been on the sidelines of the process of inclusion and citizenship, being restricted even from their right to life. The problem question seeks an understanding of the existence or not of a conceptual fabric (beyond the legal field), which can integrate the inclusion of people with disabilities (PCD's), with the bases of organizational theory, with the world of work (behavior and dynamics of companies) and with the social responsibility of companies, in order to effectively welcome people with disabilities and understand their contributions to business activities? The objective is to analyze the existence of this integrated conceptual fabric, capable of providing a better understanding of the constructs and legal aspects that define people with disabilities and their inclusion, in the field of organizational theory and social responsibility, in order to better clarify the integrative assumptions for inclusion of people with disabilities in the world of work (field of business dynamics). The research has a descriptive/exploratory nature. Its main results are summarized in the aspects of an inclusion of PCD still restricted to the legal field, with a total exclusion of the theme by organizational theory and inclusion in the business field, still being legitimized by a concept of social responsibility, which staggers, oscillates between real responsibility and fad.
\end{abstract}

Keywords: Person with disabilities; Organizational theory; Social responsibility; Inclusion.

\section{Resumen}

Los avances en la legislación de las sociedades contemporáneas han permitido nuevas perspectivas para las minorías. El Estado brasileño contempló grupos sociales victimizados por alguna forma de participación excluyente, como los 
sistemas de cuotas, mecanismo utilizado para promover la inclusión de personas con discapacidad (PDC's). Por ello, conviene recordar que las personas con discapacidad siempre han estado al margen del proceso de inclusión y ciudadanía, estando restringidas incluso de su derecho a la vida. La pregunta problema busca comprender la existencia o no de un tejido conceptual (más allá del campo jurídico), que pueda integrar la inclusión de las personas con discapacidad (PCD's), con las bases de la teoría organizacional, con el mundo del trabajo (comportamiento y dinámica de las empresas) y con la responsabilidad social de las empresas, con el fin de acoger eficazmente a las personas con discapacidad y comprender sus aportes a la actividad empresarial? El objetivo es analizar la existencia de este tejido conceptual integrado, capaz de brindar una mejor comprensión de los constructos y aspectos legales que definen a las personas con discapacidad y su inclusión, en el campo de la teoría organizacional y la responsabilidad social, con el fin de esclarecer mejor los Supuestos integradores para la inclusión de personas con discapacidad en el mundo laboral (ámbito de la dinámica empresarial). La investigación tiene un carácter descriptivo/exploratorio. Sus principales resultados se resumen en los aspectos de una inclusión de la PCD aún restringida al ámbito jurídico, con una total exclusión del tema por la teoría organizacional y la inclusión en el ámbito empresarial, aun siendo legitimado por un concepto de responsabilidad social, que tambalea, oscila entre la responsabilidad real y la moda.

Palabras clave: Persona con Discapacidad; Teoría organizacional; Responsabilidad social; Inclusión.

\section{Introdução}

Os avanços das legislações nas sociedades contemporâneas têm possibilitado um novo olhar para as minorias. O Estado brasileiro, por meio de algumas ações afirmativas, buscou contemplar grupos sociais vitimados por alguma forma de alijamento de participação cidadã e, dentre essas políticas, denota-se de fundamental importância os chamados sistemas de cotas, mecanismo utilizado para promover a inclusão da pessoa com deficiência (PDC) no mercado de trabalho, tendo sido incorporado à legislação brasileira por meio das Leis $n^{\circ} 8.112 / 90$ e 8.213/91. Tais legislações trazem o significado simbólico e material de representaram um marco para o processo de inclusão da PDC.

Assim, é extremamente válido lembrar que as pessoas com deficiências sempre estiveram à margem do processo de inclusão e cidadania, sendo tolhidas até mesmo do direito à vida, a exemplo do período pré-colonial. Para demonstrar a crueldade imposta à PCD, Figueira (2021, p. 17) relata: “Quando nascia uma criança com deformidades físicas, era imediatamente rejeitada, acreditando-se que traria maldição para a tribo, dentre outras consequências". Os argumentos para tamanha atrocidade se justificavam pela ideia de inferioridade que já existia à época e, ainda, que a pessoa com deficiência iria sofrer ao longo de sua existência as condições precárias da vida (Figueira, 2021).

Essa realidade de exclusão veio se perpetuando ao longo dos tempos, distanciando-se dessa brutalidade extrema, porém, ainda sendo vista por parte do Estado, sob uma égide assistencialista, caritativa, posto que deficiência por muito tempo foi sinônimo de doença. Esse enfoque começou a ser modificado com a introdução da Classificação Internacional de Funcionalidade (CIF), no ano de 2001 - resultado da revisão da anterior Classificação Internacional das Deficiências, Incapacidades e Desvantagens (ICIDH), uma versão experimental publicada pela Organização Mundial da Saúde (OMS) em 1980. A CIF significou um grande avanço, visto que passou a compreender a deficiência, segundo uma ótica social, diferente do que ocorria com a ICIDH, que valorava a deficiência, segundo critérios médicos.

Dentro dessa percepção social, a política pública do sistema de cotas viria a possibilitar à pessoa com deficiência uma existência, enfim, digna, haja vista que é também por meio do trabalho que uma pessoa pode encontrar os meios necessários para sua subsistência e dignidade, implicando ainda, em muitos efeitos psicológicos positivos.

Ocorre que tais legislações, ainda, só possuem um caráter quantitativo em relação ao percentual de admissão nas organizações, deixando a pessoa com deficiência desprovida de meios regulatórios que possibilitem sua efetiva inclusão e acompanhamento durante o processo laboral, seja, tanto em termos físicos (como acessibilidade, por exemplo) quanto aos meios sociais de interrelação, com as demais pessoas (acolhimento e desenvolvimento de suas capacidades e do trabalho). É com esse cenário, que tal caráter qualitativo só veio a ser disciplinado por meio da Lei n ${ }^{\circ}$ 13.146/15.

Assim, aparentemente estariam bem consolidados os aspectos de legislação. Porém, ao se pensar no acolhimento organizacional da pessoa com deficiência, precisa-se pensar nas bases teóricas ou metanarrativas que procuram explicar o 
funcionamento e a dinâmica organizacional. Nesse caso, em sentido amplo, a teoria organizacional encarregada de criar as metanarrativas para explicar e fundamentar o campo conceitual da gestão empresarial, tem se distanciado do enfrentamento deste tema, em seus compêndios, debates e publicações. Isso pode levar a uma compreensão de que, para a teoria organizacional e para o mundo do trabalho, o mais relevante é a eficiência e não a deficiência.

Assim, este estudo procura enfrentar a problemática de buscar uma melhor compreensão sobre a existência ou não de um tecido conceitual (para além do campo legal) que integre a inclusão das pessoas com deficiência (PCD), com as bases da teoria organizacional, com o mundo do trabalho (comportamento e dinâmica das empresas) e com a responsabilidade social das empresas, para efetivar o acolhimento dos PCD e compreender as suas contribuições para com as atividades empresariais?

Nesse sentido, o presente estudo tem por objetivo analisar a existência de um tecido conceitual integrado, que seja capaz de propiciar um melhor entendimento dos construtos e aspectos legais que definem pessoas com deficiência e sua inclusão, no campo da teoria organizacional e da responsabilidade social, visando esclarecer melhor os pressupostos integrativos para a inclusão das pessoas com deficiência no mundo do trabalho (campo da dinâmica empresarial).

Ao se justificar o estudo, pode-se asseverar que esta compreensão integrada só será plenamente desenvolvida à medida que a sociedade puder ressignificar as identidades humanas, se enxergar no outro, desenvolver a empatia e a solidariedade, oportunizar que as pessoas desenvolvam suas suficiências.

Cabe também, atentar para as práticas organizacionais sobre o uso de estratégias empresariais, visando apenas legitimar ações que não venham cobertas de consciência, mas apenas por uma racionalidade instrumental, de utilização das PCD e/ou os sistemas de cotas, para marcar uma posição que cai bem aos olhos da sociedade. Também se entende que ao trabalhar a existência ou não de vínculos conceituais entre legislação das PCD, responsabilidade social e teoria das organizações, pode-se reforçar os vínculos (se encontrados) ou apontar a inexistência e a possível necessidade de ampliar o debate sobre essa necessidade.

Em seu desenvolvimento, este estudo está assim delineado: a introdução, pela qual se contextualiza o estudo e introduzse a questão problemática, os objetivos e a justificativa; na seção 2, os métodos e procedimentos, sobre os quais são sedimentados os caminhos desta construção; na seção 3, a deficiência à luz da legislação brasileira e o sistema de cotas; na seção 4, a teoria organizacional e a compreensão histórica da pessoa com deficiência nas organizações; na seção 5, a responsabilidade social, como um caminho de acesso ao mundo do trabalho: obrigações legais, oportunismo ou modismo empresarial; na seção 6, as conclusões e logo a seguir, as referências.

\section{Métodos e Procedimentos}

A pesquisa possui natureza descritiva/exploratória, conforme Pádua (2016), para a qual esta orientação busca esclarecer fenômenos ainda pouco conhecidos ou que, devido ao grau de complexidade, fragmentação e interligações, não estejam ainda muito claros.

A estratégia de construção da pesquisa foi alicerçada predominantemente sob o método qualitativo que, segundo Pereira et. Al (2018, p. 67), "este método é um caminho para se realizar a análise de algum fenômeno e, quando se tem o caminho, tornase mais fácil realizar viagens sabendo o ponto de partida, o ponto de chegada e como fazê-lo". Os métodos qualitativos são aqueles nos quais é importante a interpretação por parte do pesquisador com suas opiniões sobre o fenômeno em estudo. Neles a coleta de dados muitas vezes ocorre por meio de entrevistas com questões abertas ou leitura de obras amplas e diversificadas.

Assim, seguindo essa estrutura metodológica, operacionalmente a pesquisa contou com três etapas. Uma etapa na qual se procurou uma definição para as pessoas com deficiência (PCD), a legislação brasileira sobre o tema e sobre os sistemas de cotas. Neste tópico foram consultadas as Leis no 8.112/90, 8.213/91 e 13.146/2015, além da Constituição Federal de 1988, nos artigos pertinentes ao tema.

Em uma segunda etapa, buscou-se as bases do campo da teoria das organizações, visando compreender como este 
campo trata da questão da deficiência ou da exclusão como metanarrativa. Para esse intento foram pesquisados autores basais como Reed (1999) e Morgan (2005), autores como Fineman (2001) e Gagliardi (2001), que incluem conceitos de emoção e o processo de organizar e a estética da vida organizacional, no sentido de buscar pequenos fundamentos da origem de uma possível inclusão teórica e, também, autores como Braverman (1974) e Donkin (2003), com suas visões mais críticas sobre a ideologia da teoria organizacional, como sendo em sua essência, ideológica e não inclusiva.

$\mathrm{Na}$ terceira etapa, recorreu-se ao mundo do trabalho, ou seja, aquilo que ocorre na dinâmica e no comportamento das organizações. Aqui buscou-se um breve apanhado histórico do instituto da responsabilidade social, abordado por Borger (2001) e do conceito do referido instituto trabalhado por Oliveira (1984), Duarte; Torres (2005), Chiavenato (2010) e Antunes (2016), além dos princípios abordados pelo Instituto Ethos, visando desvendar se este campo foi atraído por um nível de consciência empresarial mais elevado sobre a inclusão ou se simplesmente não passou de um modismo empresarial em busca de legitimação ou, ainda, o campo foi impelido imperativamente pela legislação.

\section{A Deficiência à Luz da Legislação Brasileira e o Sistema de Cotas}

A construção do conceito de Pessoa com Deficiência (PCD) vem sofrendo alterações no decorrer do tempo. A concepção do modelo social, é fruto do reconhecimento da pessoa com deficiência como sujeito titular de direitos em uma sociedade justa e solidária. A Constituição Federal de 1988 dispõe sobre vários dispositivos que garantem os direitos da pessoa com deficiência, no entanto, o presente estudo, busca se ater aos arts. $3^{\circ}, 5^{\circ}$ e $7^{\circ}, \mathrm{CF}^{1}$, por tratarem de direitos fundamentais, cabendo ao Estado garanti-los a todo e qualquer cidadão.

Em que pese, a intenção legislativa de consagrar igual direito a todos, a Constituição Federal, ao usar a expressão "pessoa portadora de deficiência", a exemplo do art. $7^{\circ}, \mathrm{CF}$, acaba por atuar como um meio de inferiorização e discriminação. Nesse sentido, discorre Sousa (2011, p. 33):

O uso da expressão "portadores de deficiência", muitas vezes, é utilizado pejorativamente por algumas pessoas, que veem as pessoas com deficiência como "seres inferiorizados" e "incapazes" de cumprirem com seus deveres de cidadania e, em face disso, continuam contribuindo para a permanência do preconceito existentes na sociedade.

Segundo Sassaki (2003), o entendimento das pessoas com deficiência acerca da terminologia ora em debate, se justifica pelo fato de que elas não portam a deficiência que elas têm, assim como quem porta um documento de identidade ou um guardachuva. O autor exemplifica ainda, várias expressões incorretas acerca do tema, tais como: inválidos, defeituosos, incapacitados, mongoloides, dentre outras.

A busca por uma terminologia que melhor atenda aos interesses da pessoa com deficiência, de forma que pudessem participar de um processo inclusivo na sociedade, é importante, a fim de evitar práticas discriminatórias, posto que possuem um passado marcado por atrocidades, práticas desumanas e cruéis.

A compreensão da terminologia adotada atualmente - pessoa com deficiência - sob o ponto de vista político, se faz necessária, para que a sociedade possa compreender as necessidades biopsicossociais das PCD e, assim, possa contribuir para que essas pessoas venham a ter uma vida mais digna.

Nesse sentido, é válido pontuar a evolução das políticas públicas que versam sobre o tema, que mais recentemente, têm

\footnotetext{
${ }^{1}$ CF/88: Art. $3^{\circ}$. Constituem objetivos fundamentais da República Federativa do Brasil: (...) IV - promover o bem de todos, sem preconceitos de origem, raça, sexo, cor, idade e quaisquer outras formas de discriminação; Art. $5^{\circ}$. Todos são iguais perante a lei, sem distinção de qualquer natureza, garantindo-se aos brasileiros e aos estrangeiros residentes no País a inviolabilidade do direito à vida, à liberdade, à igualdade, à segurança e à propriedade, nos termos seguintes: [...]; Art. $7^{\circ}$. São direitos dos trabalhadores urbanos e rurais, além de outros que visem à melhoria de sua condição social: (...) XXXI- proibição de qualquer discriminação no tocante a salário e critérios de admissão do trabalhador portador de deficiência.
} 
procurado abarcar a visão da pessoa com deficiência em um contexto mais abrangente. Isso é o que pode ser demonstrado com a preocupação do legislador ao resguardar a integridade das PCD, por meio do art. $2^{\circ}$ da Lei $n^{\circ} 13.146 / 2015^{2}$, que busca trazer uma definição de pessoa com deficiência, segundo um contexto, não apenas, biológico.

Na verdade, a referida Lei, conhecida como Estatuto da Pessoa com Deficiência (EPD), buscou a equiparação das concepções biológicas e psicológicas aliadas ao meio em que a pessoa com deficiência está inserida, a fim de que possa participar ativamente dos processos de desenvolvimento na sociedade. Para Diniz (2007, p. 67), "o modelo social promoveu a compreensão da deficiência como uma expressão da diversidade humana".

A acepção de um conceito novo que atendesse aos anseios da pessoa com deficiência, segundo a perspectiva dos direitos humanos, só pôde ser concebido depois da criação da Classificação Internacional de Funcionalidade (ClF) ${ }^{3}$, no ano de 2001. Esse é o entendimento de Silva (2019, p. 9):

Um dos grandes avanços com a CIF foi a alteração do modelo biomédico para o modelo biopsicossocial da deficiência, o qual esclarece que o fator limitador das pessoas com alguma deficiência é o meio em que esta se insere e não a deficiência em si. Tal abordagem deixa claro que as deficiências não indicam, necessariamente, a presença de uma doença ou que o indivíduo deva ser considerado doente por ter uma deficiência, como sugere o modelo biomédico.

Com a CIF, passou-se a avaliar impedimentos (estrutura e função do corpo), limitação nas atividades, bem como a restrição na participação social sob a concepção biopsicossocial da deficiência. Muito embora, a nova classificação introduzida pela OMS tenha trazido inovações, manteve ainda insuficiências quanto à avaliação do contexto e não se destinou a avaliar pessoas "em graus de deficiência". Os países ficaram responsáveis pela elaboração de instrumentos próprios de valoração da situação de deficiência de acordo com suas realidades culturais e socioeconômicas (Farias \& Buchalla, 2005).

Desse modo, pode-se concluir que a aplicação da CIF para a compreensão da pessoa com deficiência dentro de um contexto biopsicossocial foi um marco para o deslanchar de novas perspectivas no seio da sociedade, que levem ao reconhecimento desse grupo minoritário. Importa salientar a importância da Classificação Internacional de Doenças (CID) para o diagnóstico e o tratamento da deficiência, mas isso não basta, haja vista, que a pessoa com deficiência precisa se reconhecer como parte integrante de um mundo multiculturalista e de revalorização de identidades. Daí a importância da aplicação da CIF. Assim, a aplicação conjunta das classificações supramencionadas, veio a contribuir para os estatutos normativo-legais que compreendem a matéria nos dias de hoje, a exemplo do Estatuto da Pessoa com Deficiência.

Nesse contexto, conturbado e não pacificado, tanto conceitualmente quanto nas metanarrativas, o sistema de cotas surgiu como consequência de muitos debates acerca do tema a nível mundial e, por meio deles buscou-se a inclusão social das pessoas com deficiência, em uma tentativa de possibilitar que elas exerçam e desenvolvam em grau de igualdade suas capacidades. Nesse contexto, resta saber de que maneira as organizações vêm a contribuir com esse processo de inclusão e responsabilidade social. Essa nova realidade vem sendo paulatinamente modificada, a partir da imposição de normas legais para admissão de pessoas com deficiência nas empresas a partir da vigência das Lei $n^{\circ}$ 8.112/90 e da Lei no 8.213/91.

Antes de mais nada, é primordial compreender a ideia de que as pessoas possuem um nome, uma história, incluindo saberes, desejos, limitações, necessidades e capacidades, independentemente da classificação que recebam - deficientes ou não (Figueira, 2021). Nesse ínterim, todos são sujeitos à lógica das capacidades, cabendo a consciência social de facilitar o desenvolvimento pleno dessas capacidades adequando-se às necessidades de cada pessoa.

\footnotetext{
${ }^{2}$ Lei $n^{\circ}$ 13.146/2015: Art. $2^{\circ}$. Considera-se pessoa com deficiência aquela que tem impedimento de longo prazo de natureza física, mental, intelectual ou sensorial, o qual, em interação com uma ou mais barreiras, pode obstruir sua participação plena e efetiva na sociedade em igualdade de condições com as demais pessoas.

${ }^{3}$ A CIF se constitui de base conceitual do trabalho junto a pessoas com deficiência. Trata-se da Classificação Internacional de Funcionalidade firmada pela OMS.
} 
Há suficiência de mais ou de menos. Pessoas têm suficiências de mais ou de menos. Suficiências de menos, no amor, ao não viver o amor pleno em todas as horas. Suficiências de mais, ao ver o coração do outro mesmo sem ter olhos. Suficiências de menos, no ensino, ao não ver o aluno como fonte de aprendizado. Suficiências de mais ao acariciar o outro mesmo sem ter mãos. Suficiências de menos, na saúde pública, ao não ver o trabalho como categoria central. Suficiências de mais ao andar mais dos que têm pernas, mesmo sem ter pernas. Suficiências de menos ao não ouvir que a ciência deve servir à mudança. Suficiências de mais ao ouvir todas as vozes mesmo sem ter ouvidos. Suficiências de menos ao colocar a produção do conhecimento a serviço do mercado e do capital. Suficiências de mais ao colocar todos os sentidos a serviço da dignidade humana, mesmo que faltem todos os sentidos. Deficiências são subjetividades, aparentes ou não. Suficiências, quando de mais, são planos de ação, e, quando de menos, são capitulação. Não existem pessoas com deficiência. Existem pessoas. As que mudam o mundo são as suficientes demais (Chaveiro, E. F. e Vasconcellos, L. C. F., 2018, p. 27).

Assim, o sistema de cotas de acesso ao trabalho para pessoa com deficiência tem sua base principiológica, na Constituição Federal de 1988, em que expressou a magnitude do direito ao trabalho quando dispôs sobre ele, classificando-o como direito social ${ }^{4}$. O texto constitucional valorou o trabalho como direito universal, vedando a discriminação negativa, em razão de sexo, raça, religião, ou qualquer outra forma de segregação. Compreendendo o trabalho como direito social, cabe trazer à baila os ensinamentos de Dantas (2011, p. 199-200), segundo o qual:

É preciso aferir a noção dos direitos sociais e identificar nela a existência de elementos que decorram ou que exprimam a sobredita noção de direitos fundamentais. É preciso, então, que os direitos sociais se caracterizem como direitos que visam à satisfação de necessidades relativas bens jurídicos fundamentais pertinentes à dignidade ou à liberdade ou à igualdade, ou a todos esses princípios.

Considerando o valor social do trabalho, presente no texto constitucional, vale salientar sua importância, haja vista que, é através do trabalho, que o ser humano poderá desenvolver sua plena capacidade e resguardar uma vida digna, sendo este, materializado em condições reais de sobrevivência e aquisição de bens e ainda, satisfação pessoal.

O direito ao trabalho constitui-se como um direito social, devendo o Estado mobilizar-se para realizar políticas de pleno emprego. Isto, é claro, porque a partir do trabalho o ser humano conquista sua independência econômica e pessoal, reafirma sua capacidade produtiva, exercita sua autoestima e se insere na vida adulta definitivamente (Fonseca, 2006).

Assim, é preciso delinear o conteúdo principiológico do direito sistema de cotas, a fim de que a sociedade possa compreender e participar do processo de inclusão da pessoa com deficiência, conferindo a devida importância à ação afirmativa em destaque. Segundo Feres, Campos, Daflon, e Venturini, (2018, p. 16), define-se ação afirmativa como: “Todo programa, público ou privado, que tem por objetivo conferir recursos ou direitos especiais para membros de um grupo social desfavorecido, com vistas a um bem coletivo".

Com o intuito de compensar e valorizar identidades coletivas vitimadas por alguma forma de estigmatização é que atuam as ações afirmativas (Araújo, 2009). Nesse sentido, agindo positivamente a fim de proporcionar igualdade de oportunidades, o Estado brasileiro instituiu o sistema de cotas como meio de acesso da pessoa com deficiência no trabalho, buscando a efetividade desse direito através da norma constitucional, em seu art. 37, VIII $^{5}$, bem como através da Lei no $8.112 / 90^{6}$

\footnotetext{
${ }^{4}$ Dispõe o Art. $6^{\circ}$, CF: São direitos sociais a educação, a saúde, a alimentação, o trabalho, a moradia, o transporte, o lazer, a segurança, a previdência social, a proteção à maternidade e à infância, a assistência aos desamparados, na forma desta Constituição.

${ }^{5}$ Dispõe o Art. 37: A administração pública direta e indireta de qualquer dos Poderes da União, dos Estados, do Distrito Federal e dos Municípios obedecerá aos princípios de legalidade, impessoalidade, moralidade, publicidade e eficiência e, também, ao seguinte: (...)VIII - a lei reservará percentual dos cargos e empregos públicos para as pessoas portadoras de deficiência e definirá os critérios de sua admissão.

${ }^{6}$ Dispõe o Art. $5^{\circ}, \S 2^{\text {o}}$ : Às pessoas portadoras de deficiência é assegurado o direito de se inscrever em concurso público para provimento de cargo cujas atribuições sejam compatíveis com a deficiência de que são portadoras; para tais pessoas serão reservadas até $20 \%$ (vinte por cento) das vagas oferecidas no concurso.
} 
e da Lei $n^{\circ} 8.213 / 91^{7}$.

No entanto, as legislações pertinentes ao tema - Lei $\mathrm{n}^{\circ}$ 8.112/90 e Lei $\mathrm{n}^{\circ}$ 8.213/91 - dispõem apenas de critérios quantitativos de admissão, limitando-se a penalidade da aplicação de multa em caso de descumprimento, disciplinada através da Portaria ${ }^{\circ}$ 9, de 15 de janeiro de 2020 do Ministério da Economia ${ }^{8}$. Ocorre que, após ser contratada, a pessoa com deficiência, a depender da especificidade de sua deficiência, precisa de logística diferenciada em relação aos demais funcionários/servidores, seja no tocante à acessibilidade física no local de trabalho, na adequação de eventuais treinamentos ou ainda, na sociabilidade dentro da organização.

O Estatuto da Pessoa com Deficiência ou Lei da Inclusão da Pessoa com Deficiência (Lei no 13.146/2015), buscou efetivar os meios adequados para a consecução do trabalho da pessoa com deficiência, garantindo a igualdade de oportunidades com as demais pessoas, em especial, quanto ao disposto nos arts. $34^{9}$ e $35^{10}$, em consonância com o art. 170 da Constituição Federal ${ }^{11}$, pautando-se na valorização do trabalho humano como meio de assegurar uma vida digna a todos, pré-requisitos da ordem econômica.

Conclui-se que o trabalho do indivíduo não é apenas pautado num direito subjetivo, mas é por meio dele que a oferta de oportunidades para todos, com deficiência ou não, poderá construir uma sociedade mais equilibrada socioeconomicamente. A construção do aparato legislativo em torno da temática fundante no trabalho, como direito fundamental da pessoa com deficiência, encontra suporte em princípios universais que permeiam os direitos humanos. Nesse contexto, é interessante se perguntar como as narrativas existentes no campo da teoria organizacional acolhem esta temática sobre as inclusões e contribuições das PCD's, primeiro no campo teórico e segundo, no campo do trabalho.

\section{A Teoria Organizacional e a Compreensão Histórica da Pessoa com Deficiência nas Organizações}

Nesta seção, procurou-se por uma resposta sobre como a teoria organizacional acolhe a questão das pessoas com deficiência (PCD’s), no campo dos estudos organizacionais e no mundo do trabalho. Primeiro buscou-se uma resposta sobre duas bases teóricas importantes: os trabalhos, pela perspectiva histórica de Reed (1999) e sociológica de Morgan (2005).

O trabalho de Reed (1999) inserido no compêndio de estudos organizacionais, denominado Handbook de Estudos Organizacionais, procura analisar as bases teóricas de formação do campo da teoria organizacional, afirmando ser um espaço historicamente contestado. Este autor narra que a ascensão do "estado administrativo" simbolizou um novo modo de organização da sociedade, no qual a natureza humana foi transformada pela organização racional e científica. Visando demonstrar essa transformação, enuncia uma passagem de Wolin (1961, p. 378-383):

\footnotetext{
${ }^{7}$ Dispõe o Art. 93: A empresa com 100 (cem) ou mais empregados está obrigada a preencher de 2\% (dois por cento) a 5\% (cinco por cento) dos seus cargos com beneficiários reabilitados ou pessoas portadoras de deficiências habilitadas, na seguinte proporção: I- até 200 empregados... 2\%; II- de 201 a 500... 3\%; III- de 501 a 1.000... 4\%; IV- de 1.001 em diante.... 5\%.

${ }^{8}$ Dispõe o art. $9^{\circ}$ : A partir de $1^{\circ}$ de janeiro de 2019: [...] III - o valor da multa pela infração a qualquer dispositivo do RPS, para a qual não haja penalidade expressamente cominada no art. 283 do RPS, varia, conforme a gravidade da infração, de R\$2.411,28 (dois mil quatrocentos e onze reais e vinte e oito centavos) a $\mathrm{R} \$ 241.126,88$ (duzentos e quarenta e um mil cento e vinte e seis reais e oitenta e oito centavos).

${ }^{9}$ Dispõe o Art. 34. A pessoa com deficiência tem direito ao trabalho de sua livre escolha e aceitação, em ambiente acessível e inclusivo, em igualdade de oportunidades com as demais pessoas: $§ 1^{\circ}$ As pessoas jurídicas de direito público, privado ou de qualquer natureza são obrigadas a garantir ambientes de trabalho acessíveis e inclusivos; $\S 2^{\circ} \mathrm{A}$ pessoa com deficiência tem direito, em igualdade de oportunidades com as demais pessoas, a condições justas e favoráveis de trabalho, incluindo igual remuneração por trabalho de igual valor; $\S 3^{\circ}$ É vedada restrição ao trabalho da pessoa com deficiência e qualquer discriminação em razão de sua condição, inclusive nas etapas de recrutamento, seleção, contratação, admissão, exames admissional e periódico, permanência no emprego, ascensão profissional e reabilitação profissional, bem como exigência de aptidão plena; $\S 4^{\circ} \mathrm{A}$ pessoa com deficiência tem direito à participação e ao acesso a cursos, treinamentos, educação continuada, planos de carreira, promoções, bonificações e incentivos profissionais oferecidos pelo empregador, em igualdade de oportunidades com os demais empregados; $\S 5^{\circ}$ É garantida aos trabalhadores com deficiência acessibilidade em cursos de formação e de capacitação.

${ }^{10}$ Dispõe o Art. 35. É finalidade primordial das políticas públicas de trabalho e emprego promover e garantir condições de acesso e de permanência da pessoa com deficiência no campo de trabalho.

${ }_{11}$ Dispõe o Art. 170: A ordem econômica, fundada na valorização do trabalho humano e na livre iniciativa, tem por fim assegurar a todos, existência digna, conforme os ditames da justiça social, observados os seguintes princípios: [...] VII - redução das desigualdades regionais e sociais.
} 
Organização como forma de poder - esta foi a lição ensinada por Saint-Simon. A nova ordem seria regida não mais por homens, mas por "princípios científicos" baseados na "natureza das coisas", e, portanto, absolutamente independente da vontade humana. Dessa forma, a promessa da sociedade organizacional era o predomínio das leis científicas sobre a subjetividade humana, o que levaria ao desaparecimento completo do elemento político (...) [e a organização] é o "grande instrumento" para a transformação das irracionalidades humanas em comportamentos racionais.

Nesse contexto, as promessas das organizações modernas de crescimento de uma sociedade organizacional, avanços na razão, liberdade e justiça, erradicação da ignorância, coerção e pobreza, resolução de conflitos entre o coletivo e as vontades individuais e a resolução do conflito entre "sociedade" e "indivíduo", ficam marcadas por esta passagem e passam a fazer parte de uma narrativa de progresso e razão.

Reed (1999) afirma que uma concepção de teorização organizacional deve conter tanto o processo quanto o produto da teoria e devem ser vistos como um processo de ação e criação, realizados por pessoas em um determinado período histórico específico. Assim, a teoria organizacional é sujeita a procedimentos metodológicos comuns, mas que podem ser revisados, por intermédio de modelos e teorias explicativas a serem negociadas e debatidas. As interações e contestações de tradições intelectuais rivais implicam na existência de entendimentos negociados e relacionados a dado contexto e situação histórica, que tornam a argumentação racional possível.

Em seu trabalho, Reed (1999) apresenta três pontos, que formam a base utilizada para lincar os estudos teóricos com a proposta deste estudo. Um primeiro elemento apresentado pelo autor está no Quadro 1, sendo as narrativas analíticas em análise organizacional.

Em princípio, na síntese vista no Quadro 1, verifica-se na teoria organizacional, um distanciamento do tema da deficiência e uma aproximação rotunda com o campo da eficiência, já que esta retrata a produção, a produtividade a conquista econômica dos mercados etc. Metanarrativas, como racionalidade, mercado, poder e até mesmo conhecimento, não contém uma aproximação com a ideia de diálogo entre o mundo produtivo da eficiência com trabalhadores com deficiência. Mesmo nas transações contextuais, o Estado e as corporações não trazem essa aproximação.

Quadro 1 - Narrativas Analíticas em Análise Organizacional.

\begin{tabular}{|l|l|c|c|}
\hline $\begin{array}{c}\text { MODELO DE } \\
\text { METANARRATIVA } \\
\text { INTERPRETATIVA }\end{array}$ & $\begin{array}{c}\text { PROBLEMÁTICA } \\
\text { PRINCIPAL }\end{array}$ & $\begin{array}{c}\text { PERSPECTIVAS ILUSTRATIVAS } \\
\text { EXEMPLOS }\end{array}$ & TRANSIÇÕES CONTEXTUAIS \\
\hline Racionalidade & Ordem & Teorias Clássicas E Científicas & $\begin{array}{c}\text { Estado guarda noturno e Estado } \\
\text { Industrial }\end{array}$ \\
\hline Integração & Consenso & $\begin{array}{c}\text { Teorias das Relações Humanas, } \\
\text { sistêmica, cultura corporativa }\end{array}$ & $\begin{array}{c}\text { Do capitalismo empresarial ao } \\
\text { Capitalismo do Bem-Estar }\end{array}$ \\
\hline Mercado & Liberdade & $\begin{array}{c}\text { Teoria da firma, economia } \\
\text { institucional, custos de transação, } \\
\text { dependência de recursos }\end{array}$ & $\begin{array}{c}\text { Do capitalismo gerencial ao } \\
\text { capitalismo neoliberal }\end{array}$ \\
\hline Poder & Dominação & $\begin{array}{c}\text { Weberianos neo-radicais, marxismo } \\
\text { crítico-estrutural, teoria institucional }\end{array}$ & $\begin{array}{c}\text { Do coletivismo liberal a } \\
\text { corporativismo negociado }\end{array}$ \\
\hline Conhecimento & Controle & $\begin{array}{c}\text { Etnométodos, símbolo/cultura, teoria } \\
\text { do ator rede }\end{array}$ & $\begin{array}{c}\text { Do industrialismo e modernidade ao } \\
\text { pós-modernidade }\end{array}$ \\
\hline Justiça & Participação & $\begin{array}{c}\text { Ética nos negócios, democracia } \\
\text { industrial, teoria participativa e teoria } \\
\text { crítica }\end{array}$ & $\begin{array}{c}\text { Da democracia repressiva a } \\
\text { democracia participativa }\end{array}$ \\
\hline
\end{tabular}

Fonte: Adaptado de Reed (1999).

Assim, em linhas mais específicas, seria possível ventilar a possibilidade interpretativa, de que as metanarrativas da integração e da justiça, poderiam tangenciar uma certa aproximação, sem mencionar diretamente o tema. Na metanarrativa da interpretação, é quando os estudos organizacionais passam a incluir o indivíduo organizacional (o trabalhador) como elemento de estudos no contexto organizacional. Observando-se essa aproximação, talvez, sejam as primeiras sementes plantadas, para que mais tarde, possa-se pensar em incluir as pessoas com deficiência no conjunto dos estudos organizacionais. 
Na metanarrativa da justiça, as questões do consenso e do estado do Bem-Estar e as questões da ética e da teoria participativa, podem sinalizar com uma aproximação ao tema. De algum ponto destes, vai ser mais tarde trazidos para o campo do trabalho as inserções legais, obrigatórias. As demais metanarrativas não contém essas aproximações.

Em um segundo elemento da análise em Reed (1999), está contemplado o que este autor denominou de pontos de intersecção, os quais representam dilemas ou integrações necessárias dentro do campo teórico (ver Quadro 2).

Quadro 2 - Pontos de Intersecção.

\begin{tabular}{|l|l|}
\hline \multirow{2}{*}{ Pontos de Intersecção } & O debate atuação/estrutura \\
\cline { 2 - 2 } & O debate Construtivista/Positivista \\
\cline { 2 - 2 } & O debate individualista/coletivista \\
\hline
\end{tabular}

Fonte: Adaptado de Reed (1999).

No Quadro 2, a ideia do debate individualista e coletivista, também não inclui diretamente este tema, mas pode sinalizar um ponto futuro para um debate mais localizado, sobre o tema da inclusão dos PCD no mundo do trabalho e no campo da eficiência a partir do indivíduo.

Já no Quadro 3, este autor procura retratar um terceiro elemento o qual ele denominou de pontos de exclusão, ou seja, aquilo que a teoria ainda não foi capaz de contemplar, em suas narrativas ou não as incluiu.

Quadro 3 - Pontos de Exclusão.

\begin{tabular}{|l|l|}
\hline \multirow{3}{*}{ Pontos de Exclusão } & Gênero \\
\cline { 2 - 2 } & Raça e Etnicidade \\
\cline { 2 - 2 } & Tecnociência \\
\cline { 2 - 2 } & Desenvolvimento Global e Subdesenvolvimento \\
\hline
\end{tabular}

Fonte: Adaptado de Reed (1999).

No Quadro 3, este autor trabalhou os possíveis pontos de exclusão da teoria organizacional. Em nenhum dos pontos trazidos pelo estudo, encontra-se o campo da deficiência como ponto de exclusão. Isso pode significar uma desimportância teórica (a qual entende-se como a mais possível), uma neutralidade ou uma cegueira teórico-conceitual. Qualquer análise poderia incluir estas conclusões do trabalho.

É claro e, perfeitamente compreensível, que uma meta narrativa, não tenha o alcance de incorporar todos os grandes debates e embates que um campo teórico possuí. Uma meta narrativa possui limites de contexto, tempo/espaço e relevância dos próprios temas. Porém, pode ser um sinal claro de que o tema trazido, para o olhar deste campo, ainda não causou o impacto necessário ou chamou a atenção para ser tratado com elemento teórico de inclusão ou exclusão.

Outra análise importante e basal, para estudar a gestão das organizações é o que fazem Souza e Prado (2009), quando recorrem ao trabalho de Morgan (2005), o qual trabalha com quatro paradigmas sociológicos, que segundo ele compõem uma base ontológica e epistemológica que fundamenta as teorias organizacionais modernas, neste caso esses autores avaliaram organizações educacionais. Mas, é correto afirmar que o alcance da sociologia de Morgan (2005) vai muito além. A Figura 1 reflete um resumo da análise concebida por Morgan (2005), em sua abordagem sociológica, das organizações.

Para Morgan (2005) e Souza e Prado (2009), esse quadro paradigmático de referência dos estudos organizacionais permite que se busque entender as bases das escolas do pensamento, possibilitando o uso de metáforas e sua operacionalização por ferramentas e textos específicos, visando colaborar com a compreensão do universo organizacional. 
Figura 1 - Modelo Interpretativo de Paradigmas Organizacionais.

\section{Sociologia da Mudança Radical}

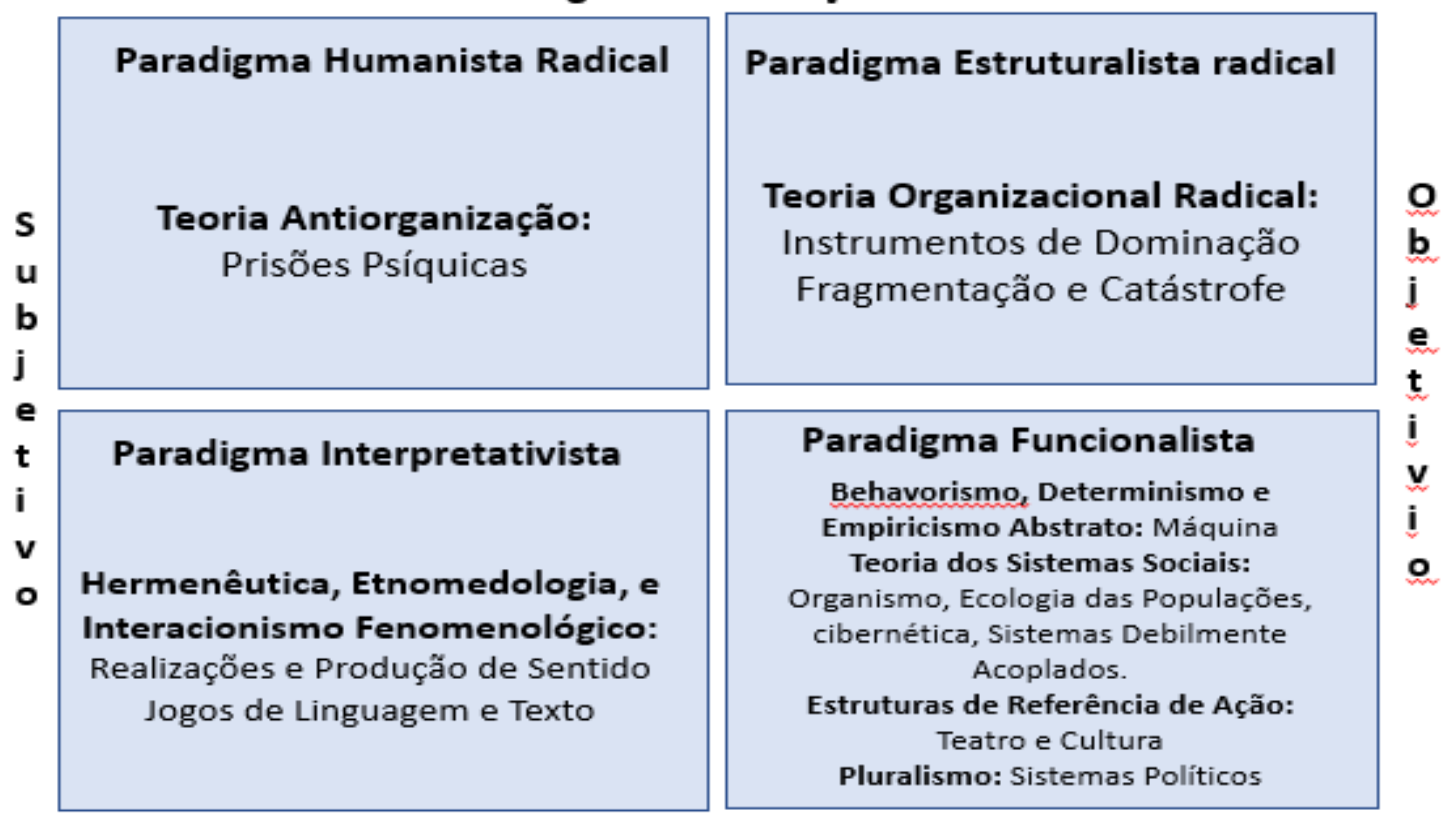

Sociologia da Regulação

Fonte: Adaptado de Morgan (2005).

Assim, somente para ilustração e esclarecimento, seguindo este quadro, autores como Caldas e Fachin (2005) procuram demonstrar que ainda é predominante a vertente funcionalista nos estudos organizacionais, muito embora, recentemente, os demais paradigmas começaram a ampliar seus estudos. Neste paradigma dominante, a razão instrumental da eficiência é a grande condutora do fator humano para o mundo do trabalho.

Cabe, nesta análise, também retratar que para Morgan (2005), a complexidade da análise organizacional demanda o uso de modelos, metáforas e ferramentas como recursos de análises. Estas abordagens configuram modelos variados de gestão, mas diante da variedade de características organizacionais, torna-se necessário aplicá-los de forma adaptativa e cuidadosa. A ideia do quadro é também para lembrar a existência das inúmeras possibilidades teóricas, não esquecendo que é possível a coexistência de modelos simultaneamente ao se analisar as organizações.

Nesta concepção, também não é possível encontrar de forma direta o tema proposto para este estudo, que é a inclusão das PCD no mundo das organizações e no mundo do trabalho. No Quadro 4, no campo mais subjetivista, estão situados os paradigmas interpretativista e humanista radical, que são capazes de acolher o tema, por seus enfoques e métodos. Destes paradigmas, podem estar situadas as raízes teóricas que possam embasar discussões teóricas futuras, sobre o campo da inclusão da PCD.

Nesse sentido, em aspectos mais específicos da teoria, cabe também destacar os trabalhos de Fineman (2001) sobre a emoção e o processo de Organizar e Gagliardi (2001) explorando o lado estético da vida organizacional.

No trabalho de Fineman (2001), o autor procura trazer para o centro da discussão da teoria organizacional o tema da emoção. Trata da questão ideológica da teoria da emoção e da emotividade e dos sentimentos no mundo do trabalho. Procura questionar (amenizando o termo) sobre o mito do ator organizacional racional, afirmando que as emoções servem a racionalidade e que ambos os termos se entrelaçam, nos contextos organizacionais e nos campos teóricos.

Já o trabalho realizado por Gagliardi (2001), trata de incluir alguns pontos que os ambientes organizacionais ora procuram mostrar e ora procuram esconder. Contempla a importância dos artefatos para os estudos das culturas organizacionais. Esses artefatos podem estar visíveis ou podem estar invisíveis ao olhar de quem observa e de quem quer ser observado. Seu 
estudo procura dimensionar a necessidade de uma nova sensibilidade para a estética organizacional e para a visibilidade dos artefatos culturais de uma organização.

Em ambos os trabalhos, pontos sensíveis da teoria das organizações são trazidos para o centro da discussão do campo, buscando demonstrar que as inclusões de pessoas com deficiências, seja nos estudos das organizações, seja no mundo do trabalho, tem uma certa guarida conceitual para um futuro acolhimento.

No campo da estética de Gagliardi (2001), toda e qualquer inclusão ou exclusão de elementos de uma cultura organizacional (os artefatos), precisariam ser legitimadas tanto pelas instâncias de poder, quanto pelas instâncias do coletivo organizacional. É neste sentido, que preparar a sociedade e as organizações para lidar com os processos inclusivos de PCD, torna-se um processo fundamental.

Já no campo do trabalho de Fineman (2001), ao tratar das emoções, a busca é por demonstrar um entrelaçamento do conceito de racionalidade com a dimensão emocional dos indivíduos dentro das organizações. Portanto, procura desmistificar o mito de um ser racional produtivo. Um ser racional produtivo, é, também, um ser emocional carregado de sentimentos e emoções, incapaz de ser divisível. Assim, este mesmo acolhimento no mundo organizacional e no mundo do trabalho, precisa ser trabalhado, para novos contextos e novas inclusões, venha elas do próprio campo organizacional, do próprio campo do mundo do trabalho ou da legislação que acolhe e impele mudanças para a sociedade, por consequência, para as organizações.

Esses autores vistos, centram-se na ideia de que a racionalidade instrumental se tornou preponderante na teoria e na dinâmica das organizações modernas. Sobre esses aspectos, denota-se a existência de inúmeras críticas sobre essa racionalidade excessiva no trabalho, as quais podem ser vistas em autores relevantes sobre o tema. Para ilustrar, Braverman (1974) faz duras críticas sobre a cientificidade do trabalho, sem o olhar diferenciado para o elemento humano. Braverman (1974) também critica a seleção científica do trabalhador, baseado apenas em seus aspectos físicos em sua crítica ao trabalho produtivo e improdutivo relata:

Por um lado, o processo de trabalho produtivo, tornou-se mais do que nunca, um processo coletivo. É apenas o corpo de trabalhadores produtivos que dá forma ao produto acabado; cada trabalhador já não pode ser considerado produtivo no sentido individual, e a definição de trabalho produtivo aplica-se apenas ao conjunto de trabalhadores. Por outro lado, o trabalho improdutivo da empresa, tendo-se expandido tão extraordinariamente, adquiriu a mesma estrutura dúplice como trabalho produtivo pela divisão capitalista do trabalho (Braverman, 1974, p. 353).

Esse aspecto também é questionado por Donkin (2003), que denominou de seleção desnatural. Para ele, o Taylorismo mostrou o caminho rumo à eficiência, com métodos de trabalho mais eficazes, insistindo que o homem de primeira classe (termo designado por Taylor no processo de seleção dos trabalhadores pelo aspecto físico), pode fazer de duas a quatro vezes o que é feito por um indivíduo mediano.

Com essas críticas trazidas, é possível compreender alguns aspectos interessantes sobre a inclusão das PCD, tanto no campo teórico quanto no campo do mundo do trabalho. Apesar dos avanços e pontos sensíveis rebuscados dentro das bases teóricas, é possível verificar o tamanho do desafio dessa inclusão, até que ela se consolide no mundo do trabalho e venha a ganhar eco dentro da teoria organizacional.

Essa inclusão, muito provavelmente, virá do contexto social (marcos legais) para o mundo do trabalho, para depois ganhar o corpo teórico. Portanto, um longo caminho a ser percorrido. Ela nasce no campo jurídico, impele-se ao campo organizacional, que vai relutar entre o acolhimento, a indiferença e a rejeição.

$\mathrm{Na}$ busca por encontrar essa intersecção, acredita-se que um dos caminhos percorridos pela legislação até o campo organizacional, possa ter ocorrido de duas formas: pelo império da Lei, já discutida na seção 3 ou pelo mecanismo da responsabilidade social, que será discutido na seção 5. 


\section{A Responsabilidade Social, como um Caminho de Acesso ao Mundo do Trabalho: Obrigações Legais, Oportunismo ou Modismo Empresarial}

Apenas para relembrar o que já está sedimentado neste estudo, como por exemplo, o contexto sociocultural da pessoa com deficiência no Brasil, que veio sofrendo significativas mudanças no decorrer do tempo, mas somente no século XX, mais precisamente a partir do ano de 1981 (Ano Internacional da Pessoa com Deficiência), que houve uma abordagem a respeito das capacidades dessas pessoas, em detrimento de suas limitações, um repensar social em relação às PCD. Tal processo culminou com a promulgação das Leis $n^{\circ}$ 8.112/90 e 8.213/91, quase 10 anos mais tarde, ambas relacionadas à obrigação legal de admissão de pessoas com deficiência nos âmbitos público e privado, respectivamente.

Verifica-se assim, que os avanços não foram gerados a partir de uma conscientização social ou de uma ampla ação institucional, mas do aprimoramento da legislação. Portanto, foram as conquistas legais que estabeleceram os marcos desses avanços. Essas diretrizes se estabeleceram devido ao reconhecimento das pessoas com deficiência como sujeitos de direitos, marginalizados ao longo de um processo histórico e que merecem um tratamento mais humano por parte da sociedade, não permitindo assim, que o setor empresarial fique alheio a esse processo. No entanto, a respeito da aplicabilidade da Lei de cotas, percebe-se que ainda existe uma lacuna acerca da qualidade no modo operacional que norteia o trabalho das PCD.

Notadamente na seção 4 deste estudo, verificou-se que no campo da teoria das organizações não foi contemplado o tema da inclusão, como elemento teórico do campo e nem como metanarrativa. Assim, presume-se que tratar da inclusão da PCD no mundo do trabalho, possa estar centrada pelos imperativos legais e estar sendo acolhido na dinâmica empresarial, por um conceito surgido com ventos muito mais mercadológicos, o da responsabilidade social.

Os primeiros delineamentos acerca do tema da responsabilidade social empresarial (RSE) se deram na primeira década do século XX, nos Estados Unidos da América, com o caso Dodge x Ford, em que se discutia sobre a competência de Henry Ford, presidente e acionista da empresa Ford, para tomar decisões que contrariassem os interesses dos demais acionistas, John e Horace Dodge. No ano de 1916, Henry Ford, sob a alegação de objetivos sociais, decidiu por não distribuir parte dos dividendos esperados, revertendo-os em investimentos na capacidade de produção, aumento de salários e fundo de reserva para a redução esperada de receitas em função do corte nos preços dos carros. A Suprema Corte julgou o caso favorável aos Dodge, tendo como fundamento que a corporação existe para o benefício de seus acionistas, não podendo usar os lucros para outros fins, sendo que a filantropia corporativa e o investimento na imagem da corporação para atrair consumidores poderiam ser realizados desde que favorecessem o lucro dos acionistas (Ashley, 2018).

A partir daí, o tema foi ganhando espaço, tendo Oliver Sheldon, como um de seus precursores, discursando sobre a existência de outros interesses dentre as preocupações das empresas, não se atendo apenas ao lucro (Pinto e Maranhão, 2011), defendendo a tese de que todo negócio existia para atender a comunidade (Mortal e Mortal, 2005). Faria e Sauerbronn (2008), assinalam que a desilusão das massas populares diante das promessas do liberalismo econômico devido à quebra da bolsa de valores de Nova Iorque, aliado ao enriquecimento de grupos empresariais que monopolizavam a economia, passaram a despertar ideais de distribuição justa de riquezas e o papel do Estado na economia, contribuindo para o surgimento acerca das ideias iniciais referentes ao instituto da RSE.

Nessa época, remonta-se, portanto, o conceito de responsabilidade social, tendo como base os princípios da filantropia e governança, manifestações paternalistas do poder corporativo. Os textos escritos nesse período, direcionam ao indivíduo o enfoque da responsabilidade/consciência social, não havendo ainda, a noção de ética vinculada ao tema (Carroll, 1999). Foi em meados dos anos 50 do século passado, que o instituto da RSE veio ganhar repercussão. Preocupados com a irresponsabilidades das empresas e seus impactos para a sociedade, pesquisadores de campo passaram a expandir seus estudos direcionados ao tema. As questões sociais, como, a pobreza, o desenvolvimento, o crescimento econômico, as relações raciais e a preocupação com a segurança no trabalho, estavam cada vez mais presentes nas discussões a nível empresarial (Borger, 2001). 
A partir da década de 1960, passou-se então, a busca pela conceituação da Responsabilidade Social Empresarial de forma mais precisa (Carroll, 1999), atribuindo-lhe então o caráter ético, que assumiu papel de destaque, advindo da filosofia e da administração. As corporações passaram a englobar características mais amplas do que o lucro, como será visto nas definições de RSE no presente capítulo.

Já na década de 1970, aprofundam-se os estudos sobre o tema. Apesar de alguns autores defenderem um posicionamento contrário à RSE, tais como Milton Friedman, alegando que a única responsabilidade da empresa é conseguir lucro, e que a empresa já é socialmente responsável à maneira que gera empregos e paga impostos, e ainda, a empresa que desvia seus recursos para fins de promoção de ações sociais poderá prejudicar sua competitividade, sendo esta atribuição de outras instituições, como governo, igrejas e ONGs, responsáveis pelo cumprimento da responsabilidade social, nota-se que por outro lado, surgem muitos autores, defendendo a teoria, com base em princípios éticos (Ashley, 2018).

Os estudos sobre RSE evoluíram significativamente no decorrer dos anos. No Brasil, o movimento passou a figurar, com mais notoriedade ao longo dos anos 90, consequência dos direitos decorrentes da Constituição Federal de 1988, do processo de redemocratização e abertura econômica. Nesse contexto, oportuno mencionar a correlação histórica entre a abertura das empresas para os fenômenos sociais pautada em valores éticos e o sistema de cotas de acesso à pessoa com deficiência no mercado de trabalho, recém-instalado no país. A Lei de Cotas, por sua vez, não se eximindo do viés social, passou a integrar como um dos elementos presentes, na esteira da responsabilidade social da empresa.

Oliveira (1984, p. 20) define Responsabilidade Social da Empresa como: “(...) capacidade da empresa de colaborar com a sociedade, considerando seus valores, normas e expectativas para o alcance de seus objetivos”. Da definição supra percebe-se que a empresa socialmente responsável não tem o capital como fim único, mas ao contrário, deve preocupar-se com questões cotidianas da sociedade, a fim de cooperar para uma sociedade mais justa, fundando-se para tanto na conciliação dos objetivos empresariais e os objetivos da sociedade. Sobre o assunto Antunes (2016, p. 179) discorre: "Procura-se, de alguma forma, uma integração entre ética, responsabilidade empresarial, direitos dos stakeholders e gestão, recorrendo-se à multidisciplinaridade de matérias como o marketing, as relações humanas, a sociologia, a economia e a política".

A empresa deve agir de acordo com os interesses de seus stakeholders - elementos chave do conceito de RSE, e que se referem a todos aqueles que são afetados diretamente pelas decisões que a empresa toma, incluindo-se no rol: acionistas, trabalhadores, consumidores, fornecedores, competidores, agências governamentais, sindicatos, residentes de comunidades locais etc. (Antunes, 2016).

A responsabilidade social empresarial (RSE) tem por fundamento que os impactos da atividade produtiva da empresa extrapolem o viés econômico, de forma a atingir a sociedade como um todo, em suas dimensões sociais, políticas, ambientais e éticas. Dessa forma, o movimento da RSE, age no sentido de sensibilizar as empresas a agir de acordo com o crescimento econômico e tecnológico, bem como de acordo com o crescimento e desenvolvimento humano sustentável. Sustentam Duarte, e Torres, (2005) e Chiavenato (2010) que nos tempos atuais a responsabilidade social da empresa vem ampliando sua abordagem, em decorrência da diversidade de aspectos socioculturais e econômicos, não cabendo apenas o cumprimento das normas legais, mas sim, avançando no sentido da proteção ativa e promoção humana, em função de um sistema definido e explicitado de valores éticos.

Melo Neto e Froes (2001, p. 100) vincula o tema ao contexto do interesse público e cidadania. Ora, não se pode falar nesses aspectos, sem mais uma vez passar pelo denso conteúdo ético que sustentam sua base ideológica. Nas palavras abaixo subscritas os autores discorrem sobre empresa cidadã.

Uma empresa-cidadã tem no seu compromisso com a promoção da cidadania e o desenvolvimento da comunidade os seus diferenciais competitivos. Busca, desta forma, diferenciar-se dos seus concorrentes assumindo uma nova postura 
empresarial - uma empresa que investe recursos financeiros, tecnológicos e de mão-de-obra em projetos comunitários de interesse público.

Nesse contexto, o presente estudo não visa esgotar o aparato teórico acerca da responsabilidade social da empresa, mas apontar os principais eixos construtivos de sua abordagem, contextualizando-a ao sistema de cotas, e compreendê-lo segundo uma das vertentes éticas da empresa. Tal contextualização deve ser analisada, não somente segundo os critérios de cumprimento do percentual mínimo estipulado pelas cotas, mas também, segundo uma análise qualitativa do instrumento legal, mais especificamente, na fase pós admissional, a exemplo das ferramentas materiais ou não, oferecidas à pessoa com deficiência como meio de desenvolvimento pleno de suas capacidades.

Considerando a necessidade de um novo olhar para grupos sociais que se encontravam à margem e nesse contexto, as empresas possuem papel determinante para a inclusão social. A Constituição Federal de 1988, pautada em valores éticos e morais, foi primordial para a construção do processo de valorização do ser humano, bastando para isso, o status de ser humano. $\mathrm{O}$ art. 170 disciplina o assunto, considerando que a ordem econômica é fundada na valorização do trabalho humano, tendo como uns dos fins a redução da desigualdade social, como já abordado na seção 2 .

O trabalho deve ser visto como uma atividade que cause prazer e orgulho para todos os que fizerem parte da organização. A responsabilidade social empresarial no contexto das cotas para pessoa com deficiência é, portanto, fundamental para o acesso ao trabalho digno dessas pessoas, uma vez que a ética empresarial compreende os valores morais e éticos de uma empresa, diante de seus clientes e concorrentes. Esses valores compreendem, inclusive o relacionamento interpessoal no ambiente de trabalho. As oportunidades disponibilizadas pela empresa para as pessoas com deficiência, respeitando sua formação profissional, fazem parte da RSE. Oferecer condições justas e favoráveis de trabalho, conforme disciplinado pela Lei $n^{\circ} 13.146 / 15$, art. 34 , § $2^{\circ}$, além de agir no cumprimento do dever legal, também concede à empresa uma boa imagem perante a sociedade.

Vale ressaltar que a imagem institucional é uma promessa. Os valores anunciados fazem parte de sua marca institucional. A esse respeito, é primordial que essa promessa seja autêntica e cumprida (Lanzer, 2017). Ora, as causas sociais contribuem significativamente para a marca institucional da empresa. Assim, estas devem agir para o estrito cumprimento da lei e ainda, oferecer todos os meios necessários para a inclusão dos trabalhadores com deficiência no âmbito laboral. Qualquer empresa que divulgar o cumprimento das cotas e não oferecer o aparato necessário, está incorrendo em irresponsabilidade social. Pois bem, traçados os delineamentos acerca da responsabilidade social da empresa, convém contrapô-los aos dados disponibilizados em sites oficiais a respeito da matéria.

Primeiramente, verifica-se uma quantidade numérica expressiva de pessoas com deficiência no Brasil. De acordo com os dados do IBGE (Instituto Brasileiro de Geografia e Estatística - Censo 2010), existem mais de 45 milhões de brasileiros que possuem algum tipo de dificuldade para ver, ouvir, se movimentar ou algum tipo de incapacidade mental. Isso representa cerca de $24 \%$ da população.

Em contrapartida, os dados mais recentes da Relação Anual de Informações Sociais (RAIS 2018) divulgado pelo Ministério da Economia, demonstram que dos 46 milhões de vínculos de emprego formal, somente 486 mil estavam direcionados às pessoas com deficiência, ou seja, menos de $1 \%$.

Os dados supracitados apontam para uma triste realidade em relação à temática. Revelam que grande parte das pessoas com deficiência no Brasil não fazem parte das estatísticas de emprego formal. Nessa senda, considerando uma defasagem de mais de 10 (dez) anos em relação ao último censo, acredita-se que as estatísticas podem ser ainda mais desfavoráveis em relação às PCD. A partir desses dados, alguns questionamentos vêm a surgir: De que maneira o Ministério do Trabalho e Emprego vem fiscalizando o cumprimento da Lei de Cotas pelas empresas? Como se dá o processo de recrutamento das pessoas com deficiência pelas empresas? As empresas estão realmente preocupadas com sua imagem institucional e com o desenvolvimento humano sustentável, uma vez que nem sempre cumprem com os preceitos legais, como é o caso da inclusão de PCD? Apesar dos avanços 
histórico-culturais e da política afirmativa do sistema de cotas, as PCD continuam sendo vistas sob a ótica do capacitismo? Tal palavra na acepção de Silva (2021) implica no: "conjunto de teorias e crenças que estabelece uma hierarquia entre os corpos considerados normais e os 'anormais', embasada em uma teoria de corponormatividade, que inferioriza os corpos de pessoas com deficiência, relegando-os à condição de incapazes"

Esses são apenas alguns questionamentos para o repensar sobre estratégias de gestão organizacional que giram em torno da pessoa com deficiência, suas aplicabilidades de forma efetiva e segundo um olhar mais sensível para as eficiências e deficiências a que todos estão sujeitos dentro do ambiente organizacional e de que maneira isso poderá implicar positiva ou negativamente na construção de uma sociedade mais solidária e justa.

O Instituto Ethos de Empresas e Responsabilidade Social ${ }^{12}$, tendo uma visão mais ampla acerca da nova acepção de responsabilidade social, que já não implica apenas em filantropia, mas no conjunto de questões sociais que circundam a empresa esquematizou os princípios de forma didática possibilitando a clareza da conectividade entre eles. Os princípios de uma forma geral, guardam profunda conectividade com a temática da pessoa com deficiência no trabalho, no entanto, destacam-se: a responsabilidade social, a valorização da diversidade e o combate à discriminação.

Nesse sentido, o Instituto supramencionado reconhece a responsabilidade social pelos resultados e impactos das ações empresariais no meio natural e social e, envidam todos os esforços no sentido de conhecer e cumprir a legislação e de, voluntariamente, exceder as suas obrigações naquilo que seja relevante para o bem-estar da coletividade. E quanto à valorização da diversidade e combate à discriminação o instituto tem como propósito, respeitar e valorizar as diferenças como condição fundamental para a existência de uma relação ética e de desenvolvimento da humanidade. Procura ainda estimular a promoção da diversidade como um diferencial positivo de desenvolvimento da sua missão e não tolera a discriminação sob qualquer pretexto.

A preocupação com o tema, levou o Instituto Ethos em parceria com a Rede Empresarial de Inclusão Social (REIS) ${ }^{13}$ a desenvolverem o Guia Temático PCD com os indicadores para a inclusão da pessoa com deficiência no mercado de trabalho. Esses indicadores surgiram em decorrência do envolvimento de várias pessoas engajadas no tema num processo de multistakeholder ${ }^{14}$, como forma de desmistificar a cultura do capacitismo e apresentar às empresas uma forma de dar maior consistência às suas práticas e reconhecer publicamente que há casos muito positivos sendo construídos, com base numa boa gestão e governança.

Porém, alerta o Instituto Ethos de Empresas e Responsabilidade Social que as empresas tenham o cuidado para não transformar o processo de inclusão em mero oportunismo ou modismo, utilizando essa ação em ações para conquistar mercados e clientes, ou seja, meramente mercadológica. Ainda pairam sobre essa narrativa da RSE ética e legítima das empresas, muitas dúvidas sobre suas verdadeiras intenções, já que o campo puramente das práticas empresariais, não é um campo altamente confiável, por conta das disputas de poder entre os próprios participantes.

Assim, considerando o contexto e as dúvidas sobre a responsabilidade social empresarial no Brasil, que permeia o assunto, resta dizer que muito ainda deve ser construído a nível organizacional, mas sementes já foram plantadas, desabrochando lentamente, por vias impositivas, mas convém lembrar que a gestão a qual atua de forma flexível orientada a identificar e a

\footnotetext{
12 Organização da Sociedade Civil de Interesse Público (OSCIP) criada em 1998, que visa mobilizar, sensibilizar e ajudar as empresas a gerirem seus negócios de forma socialmente responsável, tornando-as parceiras na construção de uma sociedade justa e sustentável, tendo como princípios: primazia da ética, responsabilidade social, confiança, integridade, valorização da diversidade e combate à discriminação, diálogo com as partes interessadas, transparência, marketing responsável, interdependência, comunidade de aprendizagem e boa governança.

${ }^{13}$ Em 02 maio de 2012, no $26^{\circ}$ Fórum de Empregabilidade Serasa Experian e com a participação de mais de 60 empresas e da Organização Mundial do Trabalho (OIT), foi lançada a ideia da criação de uma rede nacional de empregadores de pessoas com deficiência. Tem como objetivo reunir e mobilizar empresas no Brasil para promover a inclusão de pessoas com deficiência no mercado de trabalho, através do compartilhamento de conhecimentos e identificação de boas práticas, da articulação de contatos, parcerias e projetos para o desenvolvimento de produtos e serviços conjuntos, visando a qualificação profissional e a facilitação da contratação e retenção.

${ }^{14}$ Tradução: múltiplas partes interessadas.
} 
administrar as diversidades, incidirá melhores resultados para a empresa, gerando assim, impactos positivos para sua reputação, fortalecendo seu marketing social, pelo qual, o consumidor é redescoberto por meio do diálogo interativo, gerando condições de construir o processo de reflexão, participação e mudança social (Duarte \& Torres, 2005).

No entanto, cabe ressaltar que esse marketing não pode incidir tão somente em números, mas também em oportunizar qualidade de trabalho digna às pessoas com deficiência, condição essa, que se não levada em consideração, incorre em oportunismo ou modismo empresarial, distanciando-se sobremaneira, do instituto da responsabilidade social. Portanto, fugir do modismo do marketing e atingir níveis mais elevados de consciência empresarial, será em breve o grande desafio do mundo do trabalho e do campo empresarial brasileiro, mesmo porque o Brasil, como Estado-membro da Organização das Nações Unidas (ONU), comprometeu-se no cumprimento da Agenda $2030^{15}$, tendo como $8^{\circ}$ objetivo de desenvolvimento sustentável, o trabalho decente e crescimento econômico, incluindo nesse aspecto, o trabalho da pessoa com deficiência. Tal objetivo engloba a meta 8.5, sendo assim transcrita: "Até 2030, alcançar o emprego pleno e produtivo e trabalho decente todas as mulheres e homens, inclusive para os jovens e as pessoas com deficiência, e remuneração igual para trabalho de igual valor" (grifos nossos).

Pelo exposto, não há como atingir o cumprimento da Agenda 2030, no que concerne ao $8^{\circ}$ objetivo, sem perpassar pelo instituto da RSE, como meio de oportunizar a inclusão da pessoa com deficiência no trabalho, voltando-se nesse sentido, não apenas ao número de pessoas contratadas, mas visando atingir o conteúdo da dignidade humana, caracterizando-se pelo trabalho decente.

\section{Conclusão}

Assim, este estudo procurou enfrentar a problemática de buscar uma melhor compreensão sobre a existência ou não de um tecido conceitual (para além do campo legal) sobre a inclusão das PCD e com o objetivo de analisar essa existência de tecido conceitual integrado, que seja capaz de propiciar um melhor entendimento dos construtos e aspectos legais que definem pessoas com deficiência e sua inclusão, no campo da teoria organizacional e da responsabilidade social, visando esclarecer melhor os pressupostos integrativos para a inclusão das pessoas com deficiência no mundo do trabalho (campo da dinâmica empresarial).

Nesse contexto, entende-se que o objetivo foi plenamente atingido e a situação problemática mais bem esclarecida. Em uma primeira aproximação, não foram encontrados nas bases teóricas (metanarrativas) analisadas, indícios claros de que o tema da inclusão de PCD para o mundo do trabalho, tenha guarida ou acolhimento de forma direta por parte do campo teórico. Apenas, alguns elementos encontrados poderão servir como terreno fértil para que as futuras sementes de uma inclusão, possam dar frutos e gerar uma metanarrativa teórica. No trabalho de Reed (1999) nas metanarrativas da integração e da justiça (Quadro 1) e no trabalho de Morgan (2005) nos quadrantes subjetivistas do interpretativismo e do humanismo radical.

Separadamente, os trabalhos de Fineman (2001) e Gagliardi (2001), com os temas das emoções e da estética no trabalho (campo teórico), também são importantes pelos temas e direcionamentos para estudos futuros no campo, também contendo espaço fértil para que um tema como inclusão possa ser desenvolvido. Ademais, são claras as críticas anteriormente feitas, pelos autores Braverman (1974) e mais atuais com Donkin (2003), as quais sinalizam com uma prevalência da eficiência e da racionalidade instrumental do campo teórico organizacional.

\footnotetext{
${ }^{15}$ A Agenda 2030 consiste em uma declaração com um plano de ação para as pessoas, o planeta e a prosperidade, que busca fortalecer a paz universal. Surgiu em decorrência da reunião de representantes de 193 Estados-membros da Organização das Nações Unidas (ONU), ocorrida no ano de 2015. Nessa reunião, reconheceram que a erradicação da pobreza em todas as suas formas e dimensões, incluindo a pobreza extrema, é o maior desafio global e um requisito indispensável para o desenvolvimento sustentável. Através do documento "Transformando o Nosso Mundo: A Agenda 2030 para o Desenvolvimento Sustentável" (A/70/L.1), os países se comprometeram a tomar medidas ousadas e transformadoras a fim de promover o desenvolvimento sustentável nos próximos 15 anos. Possui 17 objetivos de desenvolvimento sustentável (ODS), 169 metas para cumprimento que estabelecem meios de implementação e de parcerias globais, bem como um roteiro para acompanhamento e revisão. Os ODS são o núcleo da Agenda e deverão ser alcançados até o ano 2030.
} 
Nesse sentido, a teia ou base conceitual restringe-se apenas a deixar algumas possibilidades de introdução futura do elemento ou objeto da inclusão, principalmente da PCD no mundo do trabalho. Assim, restaram dois olhares: o olhar dos marcos legais e o olhar da responsabilidade social.

Quanto aos aspectos dos marcos legais, estes ficaram claramente estabelecidos. Recém comemorados os seus 30 anos de existência, impõe-se um dever moral de analisar o percurso histórico-social da Lei de Cotas para pessoa com deficiência no mercado de trabalho, desde sua implantação até os dias de hoje, seu "modus operandi", sua aplicabilidade e efetividade numa sociedade moderna. Verifica-se que o sistema de cotas buscou favorecer a inclusão social da pessoa com deficiência, deixando uma extensa lacuna sobre o modo como tal processo deveria acontecer.

Nesse contexto, é preciso um repensar sobre a inclusão social da pessoa com deficiência no trabalho, se o sistema de cotas, ao invés de propiciar uma reintegração da PCD, não está contribuindo para um novo processo de exclusão e acepção da teoria do capacitismo desse grupo social. É bem verdade que no campo jurídico, significou uma profunda evolução de direitos e garantias, mas sob o ponto de vista sociopolítico, não basta simplesmente cumprir as cotas - fato que muitas vezes sequer acontece - é preciso ir mais além. Diferentemente de como ocorre na atualidade, a transformação deve ser social; não esperar que o indivíduo, tratando-se neste estudo, da pessoa com deficiência (PCD) venha a se exaurir numa tentativa de capacidade pré convencionada de tentar ser igual aos outros, de tentar se ajustar. Trata-se de um processo novo, árduo e de interdependência entre Estado, governo, sociedade civil e organizações, de cumprir o pacto social estabelecido pela Constituição Federal de 1988, no que diz respeito à igualdade e à dignidade humana.

Já pela perspectiva da responsabilidade social, no Brasil, impelida pelos marcos legais, vai forçosamente e vagarosamente tratando sobre essa inclusão. Portanto, a inclusão no mundo do trabalho da PCD, passa a ocorrer muito mais por força da legislação do que por um nível de consciência do empresariado. Assim, a inclusão não está na teia integrativa da teoria organizacional. Ela atinge as organizações de dentro para fora, por força da legislação, tendo sido criado este jargão de responsabilidade social ou empresas socialmente responsáveis, para que de alguma forma o tema da inclusão possa estar legitimado práticas organizacionais perante a sociedade e as empresas, muito mais como modismos, ações de marketing social, cumprimento da Lei e, muitas das vezes, sem o devido acolhimento profissional, mas apenas contratando. É correto afirmar, também, sobre a possibilidade de que algumas empresas e empresários, já o façam por consciência. Não é interessante negar esta possibilidade, sem antes esgotar a investigação.

É claro que em um tema com esse nível de conflito, possam estar refletidas muitas limitações de alcance em um único trabalho. Cabe aqui destacar que outras pesquisas podem ser realizadas demonstrando em números, em contribuições, em formas de acolhimento etc. Até mesmo porque, esse processo que inicialmente não está ocorrendo de forma espontânea, merece ser acolhido pelas organizações, de modo que, a inclusão não ocorra tão-somente por meio de imperativos legais, mas também, e principalmente, pela compreensão do tema, iniciativa empresarial e desenvolvimento de uma gestão empresarial compromissada com a ética e disposta a desenraizar preconceitos que se perduram através dos tempos.

\section{Referências}

Agenda 2030. http://www.agenda2030.com.br/

Antunes, L. (2016). Empresa e Sociedade: Responsabilidade Social, Cidadania Corporativa e Valor Partilhado. Luís Antunes Editora. E-book.

Araújo, J. C. E. (2009). Ações Afirmativas e Estado Democrático Social de Direito. LTr.

Ashley, P. (2018). Ética, responsabilidade social e sustentabilidade nos negócios: (Des)construindo limites e possibilidades. Saraiva. E-book.

Borger, F. G. (2001). Responsabilidade social: efeitos da atuação social na dinâmica empresarial. 2001. Tese (Doutorado em Administração) - Faculdade de Economia, Administração e Contabilidade, USP, São Paulo.

Braverman, H. (1974). Trabalho e Capital Monopolista: A Degradação do Trabalho no Século XX. (2a ed.), Zahar Editores. 
Caldas, M. P. \& Fachin, R. (2005). Paradigma Funcionalista: Desenvolvimento de Teorias e Institucionalismo nos anos 1980 e 1990. Revista de Administração e Empresas. 2 (45), 46-51.

Carroll, A. (1999). Corporate social responsibility: evolution of a definitional construct. Business and Society. 3 (38), 268-295. https://www.researchgate.net/publication/282441223_Corporate_social_responsibility_Evolution_of_a_definitional_construct.

Chaveiro, E. F. \& Vasconcellos, L. C. F. (2018). Cartografias existenciais - Premissas de uma leitura. In: Chaveiro, E. F. \& Vasconcellos, L. C. F. (org.). Uma ponte ao mundo - Cartografias existenciais da pessoa com deficiência e o trabalho. Kelps. E-book.

Chiavenato, I. (2010). Comportamento organizacional. Elsevier.

Classificação Internacional de Funcionalidade (CIF). (2021). http://pcd.mppr.mp.br/pagina-14.html.

Código de Conduta. Instituto Ethos. (2018). https://www3.ethos.org.br/wp-content/uploads/2018/04/C\%C3\%B3digo-de-Conduta_A4_links.pdf.

Constituição da República Federativa do Brasil (1988). http://www.planalto.gov.br/ccivil_03/constituicao/constituicao.htm.

Dantas, M. C. (2011). Direito Fundamental ao Máximo Existencial. Tese de Doutorado. Universidade Federal da Bahia. http://repositorio.ufba.br/ri/handle/ri/8703.

Diniz, D. (2007). O que é deficiência. São Paulo: Braziliense. E-book.

Donkin, R. (2003). Sangue, Suor e Lágrimas: A Evolução do Trabalho. M.Books.

Duarte, C. O. S. \& Torres, J. Q. R. (2005). Responsabilidade Social Empresarial: dimensões históricas e conceituais. In: Garcia, B. G. (Org.) Responsabilidade social das empresas: a contribuição das universidades. Vol. 4. São Paulo: Peirópolis.

Faria, A. \& Sauerbronn, F. F. (2008). A responsabilidade social é uma questão de estratégia? Uma abordagem crítica. Revista de Administração Pública. 1 (42), 7-33. https://www.scielo.br/j/rap/a/L8QTLtdJhKwzBgzPzBHv69h/?lang=pt\&format=pdf.

Farias, N. \& Buchalla, C. M. (2005). A classificação internacional de funcionalidade, incapacidade e saúde. Revista Brasileira de Epidemiologia, São Paulo, 2 (8), 187-193. http://www.scielo.br/pdf/rbepid/v8n2/11.pdf.

Feres, J., Campos, L. A., Daflon, V. T. \& Venturini, A. C. (2018). Ação afirmativa: conceito, história e debates. EDUERJ. E-book.

Figueira, E. (2021). As pessoas com deficiência na história do Brasil: uma trajetória de silêncios e gritos! (4a ed.), Wak. E-book.

Fineman, S. (2001). Teorização Organizacional: Um Campo Historicamente Contestado. In. Clegg, S. R.; Hardy, C.; Nord, W. R. Handbook de Estudos Organizacionais. Atlas.

Fonseca, R. T. M. (2006). O Trabalho da Pessoa com Deficiência e a Lapidação dos Direitos Humanos: o direito do trabalho, uma ação afirmativa. São Paulo: LTr, 2006.

Gagliari, P. (2001). Teorização Organizacional: Um Campo Historicamente Contestado. In. Clegg, S. R.; Hardy, C.; Nord, W. R. Handbook de Estudos Organizacionais. v. 2. São Paulo: Atlas.

IBGE - Instituto Brasileiro de Geografia e Estatística. Pessoas com Deficiência. https://educa.ibge.gov.br/jovens/conheca-o-brasil/populacao/20551-pessoascom-deficiencia.html.

Laudo Médico para Deficientes Esclarecimentos e Dúvidas. (2021). https://www.deficienteonline.com.br/laudo-medico-para-deficientes-esclarecimentos-eduvidas_81.html.

Lanzer, F. (2017). Clima e Cultura Organizacional: entender, manter e mudar. (2a ed.), CreateSpace. E-book.

Lei $n^{\circ} 8.112 / 1990$, de 11 de dezembro de 1990. Dispõe sobre o Regime Jurídico dos Servidores Públicos Civis da União, das autarquias, inclusive as em regime especial, e das fundações públicas federais. http://www.planalto.gov.br/ccivil_03/leis/18112cons.htm.

Lei $n^{o}$ 8.213/1991, de 24 de julho de 1991. Dispõe sobre os Planos de Benefícios da Previdência Social e dá outras providências. http://www.planalto.gov.br/ccivil_03/leis/18213cons.htm.

Lei $n^{o}$ 13.146/2015, de 06 de julho de 2015. Institui a Lei Brasileira de Inclusão da Pessoa com Deficiência. http://www.planalto.gov.br/ccivil_03/_ato20152018/2015/lei/113146.htm.

Melo Neto; F, P. \& Froes, C. (2001). Gestão da responsabilidade social corporativa: o caso brasileiro. Qualitymark.

Ministério do Trabalho e Emprego. Programa de Disseminação das Estatísticas do Trabalho. Relação Anual de Informações Sociais (RAIS), Brasília. https://www.gov.br/trabalho/pt-br.

Morgan, G. (2005). Paradigmas, Metáforas e Resolução de Quebra-Cabeças na Teoria das Organizações. Revista de Administração de Empresas. 1 (45), 58 -71.

Mortal, A. M. \& Mortal, A. B. (2005). Uma visão actual da responsabilidade social das empresas. IX Congresso Internacional de Custos. Florianópolis - SC, 28 a 30 nov. https://anaiscbc.emnuvens.com.br/anais/article/view/2015/2015.

Oliveira, J. A. (1984). Responsabilidade social em pequenas e médias empresas. Revista de Administração de Empresas. Rio de Janeiro: Fundação Getúlio Vargas, 4 (24), 203-210. https://rae.fgv.br/sites/rae.fgv.br/files/artigos/10.1590_S0034-75901984000400024.pdf. 
Research, Society and Development, v. 10, n. 11, e289101119694, 2021

(CC BY 4.0) | ISSN 2525-3409 | DOI: http://dx.doi.org/10.33448/rsd-v10i11.19694

Pádua, E. M. M. (2016). Metodologia da Pesquisa: Abordagem teórico-prática. Papirus.

Pinto, M. R.; Maranhão, C. M. (2012). Responsabilidade Social Empresarial: Reflexões à Luz dos Estudos Críticos em Administração. Revista Eletrônica de Gestão Organizacional. 3 (10), 705-726. http://www.spell.org.br/documentos/ver/10816/responsabilidade-social-empresarial--reflexoes---

Portaria $n^{\circ}$ 9, de 15 de janeiro de 2009. Ministério da Economia. Gabinete do Ministro. Dispõe sobre o reajuste dos benefícios pagos pelo Instituto Nacional do Seguro Social - INSS e dos demais valores constantes do Regulamento da Previdência Social - RPS. Diário Oficial da União, Brasília, DF, 16 jan. 2019. https://www.in.gov.br/materia/-/asset_publisher/Kujrw0TZC2Mb/content/id/59253484.

Rede Empresarial de Inclusão. Pela Empregabilidade das Pessoas com Deficiência. https://www.redeempresarialdeinclusao.com/

Reed, M. (1999). Teorização Organizacional: Um Campo Historicamente Contestado. In. Clegg, S. R.; Hardy, C.; Nord, W. R. Handbook de Estudos Organizacionais. Atlas.

Sassaki, R. K. (2003). Terminologia sobre deficiência na era da inclusão. https://www.ocuidador.com.br/imgs/utilidades/terminologia-50aa23697289a.pdf.

Silva, L. C. L (2021). Capacitismo. O que é isso? E-book

Silva, M. M. R. G. (2019). Deficiências e Saúde: revendo modelos e conceitos. Módulo 2. Curso acessibilidade e os princípios do SUS: Deficiências e saúde: revendo modelos e conceitos. Fiocruz/Icict. E-book.

Sousa, A. N. (2011). O Sistema de Cotas de Acesso ao Mercado de Trabalho para Pessoas com Deficiência. Consulex: Brasília.

Souza, S. \& Prado, V. J. (2009). Imagens Da Escola Como Organização: Uma Análise Comparativa Entre o Modelo Burocrático e a Anarquia Organizada através de Metáforas. XXXIII Encontro da ANPAD. São Paulo. De 19 a 23 de setembro.

Wolin, S. (1961). Politics and Viston. Allen and Unwin, 